\title{
In water multicomponent synthesis of low-molecular-mass 4,7-dihydrotetrazolo[1,5-a]pyrimidines
}

\author{
Irina G. Tkachenko ${ }^{1,2,3}$, Sergey A. Komykhov ${ }^{* 1,2}$, Vladimir I. Musatov ${ }^{1}$, \\ Svitlana V. Shishkina ${ }^{1,2}$, Viktoriya V. Dyakonenko ${ }^{1}$, Vladimir N. Shvets ${ }^{4}$, \\ Mikhail V. Diachkov ${ }^{5}$, Valentyn A. Chebanov ${ }^{1,2}$ and Sergey M. Desenko ${ }^{1,2}$
}

\section{Full Research Paper}

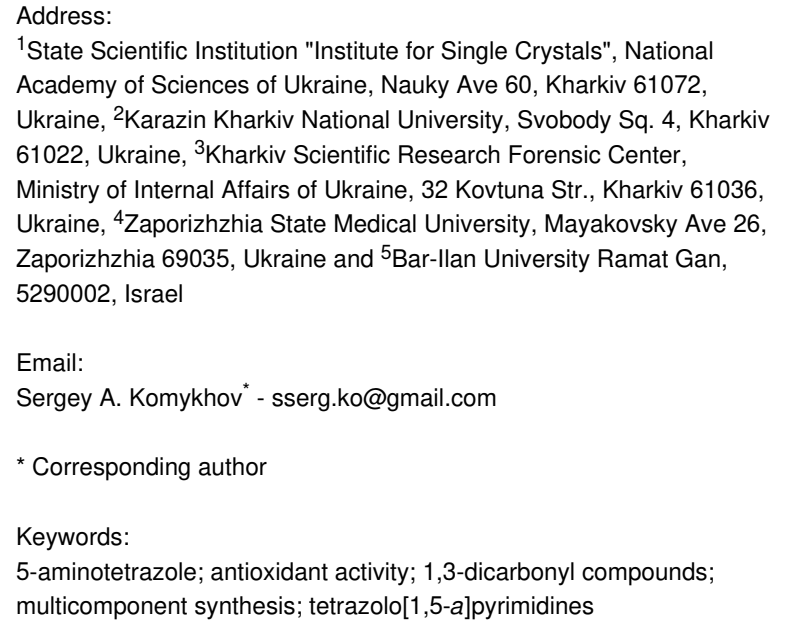

1State Scientific Institution "Institute for Single Crystals", National Academy of Sciences of Ukraine, Nauky Ave 60, Kharkiv 61072, Ukraine, ${ }^{2}$ Karazin Kharkiv National University, Svobody Sq. 4, Kharkiv 61022, Ukraine, ${ }^{3}$ Kharkiv Scientific Research Forensic Center, Ministry of Internal Affairs of Ukraine, 32 Kovtuna Str., Kharkiv 61036, Ukraine, ${ }^{4}$ Zaporizhzhia State Medical University, Mayakovsky Ave 26, Zaporizhzhia 69035, Ukraine and ${ }^{5}$ Bar-Ilan University Ramat Gan, 5290002, Israel

Email:

Sergey A. Komykhov ${ }^{*}$ - sserg.ko@gmail.com

* Corresponding author

\section{Keywords:}

5-aminotetrazole; antioxidant activity; 1,3-dicarbonyl compounds; multicomponent synthesis; tetrazolo[1,5-a]pyrimidines

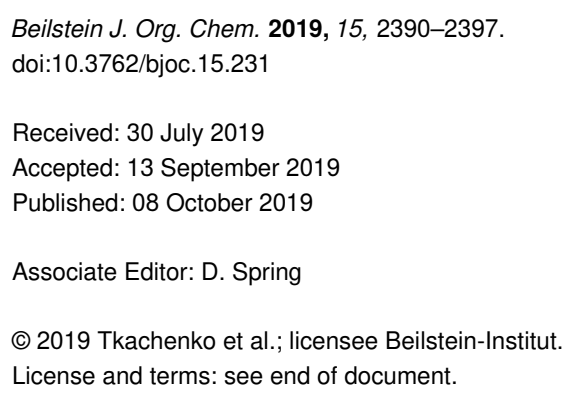

\begin{abstract}
The three-component reaction of 5-aminotetrazole with aliphatic aldehydes (formaldehyde, acetaldehyde) and acetoacetic ester derivatives in water under microwave irradiation leads to the selective formation of 4,7-dihydrotetrazolo[1,5- $a$ ]pyrimidine derivatives. Under similar conditions using 4,4,4-trifluoroacetoacetic ester 5-hydroxy-4,5,6,7-tetrahydrotetrazolo[1,5-a]pyrimidines are obtained. The analogous reaction with acetylacetone requires scandium(III) triflate as catalyst. The antioxidant activity of selected compounds was assayed with 1,1-diphenyl-2-picrylhydrazyl.
\end{abstract}

\section{Introduction}

Tetrazolo[1,5- $a$ ]pyrimidines and their partially hydrogenated derivatives are known for their interesting biological properties. They have been reported to have anticancer [1], antimicrobial [2,3] and antioxidant [3] activities and to act as inhibitors of hepatitis B virus [4]. The dihydro derivatives of tetrazolo[1,5a]pyrimidines belong to a bit special kind of dihydropyrimidines due to the strong electron-withdrawing properties of the tetrazole ring, which makes them useful for studying various theoretical issues, e.g., tautomerism [5], intramolecular transformations [6], etc.

There are several approaches to the synthesis of 4,7-dihydrotetrazolo[1,5-a]pyrimidines. Two of them make use of 5-aminotetrazole as a starting material and subsequent dihydropyrimi- 
dine ring formation. The first approach [6,7] represents a twocomponent cyclocondensation of 5-aminotetrazole (1) as binucleophilic component and bielectrophilic $\alpha, \beta$-unsaturated carbonyl compounds 2 (Scheme 1, reaction 1). The second method [8-12] comprises the three-component reaction of amine 1 with the synthetic precursors of the unsaturated ketone 2 (Scheme 1, reaction 2), i.e., carbonyl compound $\mathbf{4}$ and a methylene-active compound $\mathbf{5}$. These approaches are general and useful for the preparation of variety of dihydroazolopyrimidines which is easily accessible by variation of the binucleophilic component 1 (instead of 1, 3-amino-1,2,4-triazole, 2-aminobenzimidazole, 3-aminopyrazoles, 4-amino-1,2,3-triazoles, etc. can be used [13]). However, a relatively low reactivity of amine $\mathbf{1}$ due to the electron deficiency of the tetrazole ring has been reported several times [5,6]. A third approach (Scheme 1, reaction 3) is completely different and consists of the tetrazole ring formation through cyclization of dihydropyrimidinethiones with sodium azide [14].

Generally, all three approaches allow for the preparation of a broad range of compounds 3 with a wide variety of substituents $\mathrm{R}^{1}-\mathrm{R}^{3}$. However, the vast majority of reported data [5-12,1418] comprises aryl-substituted azolopyrimidines (with either $R^{1}$ or $\mathrm{R}^{3}$ or both being aromatic substituents), and there are only a view examples of compounds $\boldsymbol{3}$ having no aryl substituent $[19,20]$. The reason for this relatively low synthetic availability might be due to their higher solubility (compared to aryl-substituted analogues) and difficulties associated with their isolation.

Further, to address green chemistry principles [21-24] for the synthesis of dihydrotetrazolopyrimidines one may concern carrying out these reactions under solvent-free conditions [1517] or using water as a "green solvent" [18].

\section{Results and Discussion Synthesis}

Due to the small number of reports available for dihydroazolopyrimidines with aliphatic substituents, we aimed by this work to synthesize a range of dihydrotetrazolo[1,5- $a]$ pyrimidines containing no aromatic substituents. The second important reason for our interest in these compounds is based on the Lipinski rules for orally active drugs [25]. According to one of them, drug-like molecules should have molecular masses lower than $500 \mathrm{Da}$. Therefore, the minimization of molecular masses for the targeted tetrazolo[1,5- $a$ ]pyrimidines can be achieved by exclusion of large aryl substituents from their structures. Thus, we selected aliphatic aldehydes, i.e., formaldehyde and acetaldehyde, as the starting material and chose a multicomponent approach to minimize the number of reaction steps according to green chemistry principles as well. Based on our recent research [26-28], where water proved to be an effective solvent for the multicomponent synthesis of low-molecular-mass dihydroazolopyrimidines, we decided to use water also in this case.

The three-component reactions of 5-aminotetrazole (1) with aldehydes 7a,b (paraformaldehyde, acetaldehyde) and a set of acetoacetic ester derivatives $\mathbf{8 a}-\mathbf{d}$ in water under microwave irradiation at $100{ }^{\circ} \mathrm{C}$ led to the formation of the corresponding 5,6,7-trisubstituted 4,7-dihydrotetrazolo[1,5-a]pyrimidines 9a-g as single products. No formation of isomeric compounds 9' was observed in any case (Scheme 2). Increasing the temperature (to $130{ }^{\circ} \mathrm{C}$ ) and prolongation of the reaction time did not improve the yields of $\mathbf{9}$, while decreasing the temperature to $80{ }^{\circ} \mathrm{C}$ resulted in a reduced yield.

The structures of all products $9 \mathbf{a}-\mathbf{g}$ were proven by their spectral data. For example, the ${ }^{1} \mathrm{H}$ NMR spectra of $\mathbf{9 a}-\mathbf{c}$ contained

reaction 1 :<smiles>[R1]C=C([R])C([R])=O</smiles>

1<smiles>CI</smiles>

reaction 2 :<smiles>[R]CC([R])=O</smiles>

reaction 3:<smiles>[R]C1=C([R])C([R])n2nnnc2N1</smiles>

3<smiles>[R]C1=C([R])C([R])NC(=S)N1</smiles>

6 


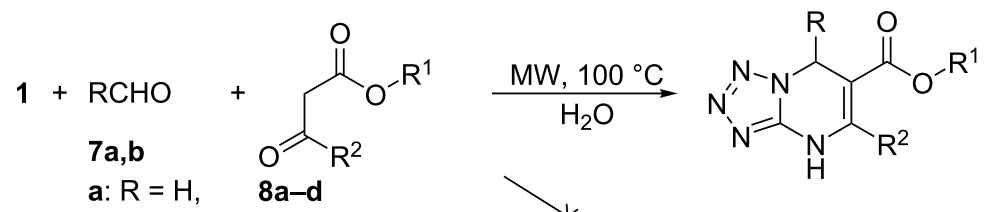

$$
\begin{aligned}
& \text { b: } R=M e \\
& \text { a: } R^{1}=E t, R^{2}=M e \\
& \text { b: } \mathrm{R}^{1}=\mathrm{Et}, \mathrm{R}^{2}=n-\mathrm{Pr} \\
& \text { c: } \mathrm{R}^{1}=\left(\mathrm{CH}_{2}\right)_{2} \mathrm{OMe}, \mathrm{R}^{2}=\mathrm{Me} \\
& \text { d: } \mathrm{R}^{1}=t-\mathrm{Bu}, \mathrm{R}^{2}=\mathrm{Me}
\end{aligned}
$$

Scheme 2: Three-component reaction of $\mathbf{1 , 7 a , b}$ and $\mathbf{8 a - d}$ in water.

singlets for $\mathrm{NH}(10.84-10.90 \mathrm{ppm})$ and $\mathrm{CH}_{2}(5.06-5.08 \mathrm{ppm})$ protons that corresponded to the 4,7-dihydro structure of the tetrazolo[1,5- $a$ ]pyrimidines. Further, five basic signals were observed in the ${ }^{13} \mathrm{C}$ NMR spectrum for the dihydrotetrazolopyrimidine bicycle: one signal was in the aliphatic area, three signals appeared at lower field, and one signal (C-6 of the bicycle) was observed between aliphatic and unsaturated carbons (92.5-92.7 ppm) which is typical for these compounds. Although the NMR data corresponded quite well to the proposed structure 9, they did not allow the complete rejection of the isomeric structure 9' for the reaction product. The final confirmation of structures $\mathbf{9 a - g}$ was achieved by X-ray analysis of $\mathbf{9 a}$ (Figure 1).

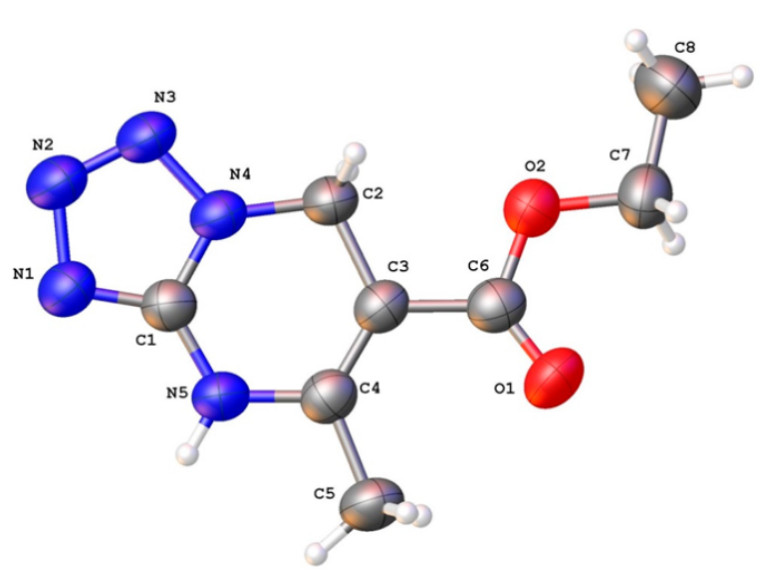

Figure 1: Molecular structure of 9a according to X-ray data. Displacement ellipsoids are shown at the $50 \%$ probability level.

A specific behavior of acetylacetone (10) as the 1,3-dicarbonyl compound was observed in the three-component reaction. Reacting it with amine $\mathbf{1}$ and aldehyde 7a under conditions similar to those for acetoacetic esters $(\mathbf{8 a}-\mathbf{d})$ led to formation of a mixture of compounds $\mathbf{1 1}$ and $\mathbf{1 2}$ (Scheme 3). Heteroaromatic tetrazolopyrimidine $\mathbf{1 1}$ was obtained as a single product from the three-component process performed at room temperature. Its structure based on NMR spectral data corresponded to a two-component condensation of amine $\mathbf{1}$ and acetylacetone (10). The selective formation of the target compound $\mathbf{1 2}$ was achieved in the presence of scandium(III) triflate as a catalyst.

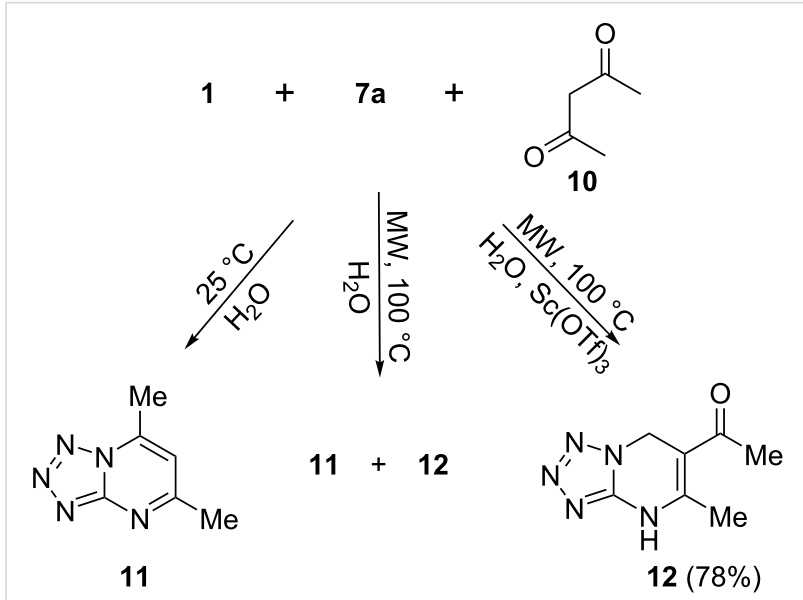

Scheme 3: Three-component reaction of 5-aminotetrazole (1) with formaldehyde (7a) and acetylacetone (10).

Another example of a 1,3-dicarbonyl compound that often exhibits unusual behavior in the three-component synthesis of azolopyrimidines [27,29] is ethyl 4,4,4-trifluoroacetoacetate (13). In these transformations, the last reaction step, a water elimination, sometimes does not occur, and the final product is the 5-hydroxy-containing tetrahydro derivative. In our experiments, the three-component reaction of amine 1 with aldehyde $\mathbf{7 b}$ and compound $\mathbf{1 3}$ in water under microwave irradiation afforded tetrahydro derivative $\mathbf{1 4}$ as a mixture of two stereoisomers. Inspection of the mixture by ${ }^{1} \mathrm{H}$ NMR revealed isomer $\mathbf{A}$ as the major component and isomer $\mathbf{B}$ as minor component in a ratio of $\approx 55: 45$. The ${ }^{1} \mathrm{H}$ NMR spectrum of 14 contained a double set of signals for two methyl and one methylene group, two signals for methine protons and two singlets for $\mathrm{NH}$ and 
$\mathrm{OH}$ protons. The NOESY experiment allowed us to accomplish the final confirmation of the structure and to establish the relative stereochemistry of both stereoisomers. NOESY cross-peaks between signals of $\mathrm{NH}$ and $\mathrm{OH}$ protons revealed that $\mathbf{A}$ and $\mathbf{B}$ are in fact stereoisomers, rejecting the regioisomeric structure 14'. The different ${ }^{3} J$ values between $6-\mathrm{H}$ and $7-\mathrm{H}$ for both isomers $(4.4 \mathrm{~Hz}$ for $\mathbf{A}$ and $11.2 \mathrm{~Hz}$ for $\mathbf{B})$ are indicative of different relative orientations of these protons and suggested that these protons in isomer $\mathbf{B}$ have trans-orientation, whereas those in isomer A have cis-orientation. Further, NOE between methyl and hydroxy groups for $\mathbf{B}$ isomer and a merely weak NOE for those groups in isomer $\mathbf{A}$ further allowed to propose a cis-orientation of these substituents for isomer $\mathbf{B}$ and the opposite one for A (Scheme 4).

\section{Antioxidant properties of $\mathbf{9}, \mathbf{1 1}, 14$}

Among the methods for the antioxidant activity (AOA) estimation, using 1,1-diphenyl-2-picrylhydrazyl (DPPH) is one of the most common and widespread [30-33]. The free radical scavenging activity of tetrazolo[1,5- $a$ ] pyrimidines 9d,f, 11, and $\mathbf{1 4}$ was measured spectrophotometrically as percentage of reducing the free-radical concentration in the presence of a test compound in methanol/dimethyl sulfoxide solutions. Ascorbic acid served as positive control. Among the tested compounds $9 f$ showed the best results at $10^{-3} \mathrm{~mol} / \mathrm{L}$ concentration and compound 9d exhibited the highest AOA at the other tested concentrations. The results of the radical scavenging experiments are collected in Table 1 and are promising for further detailed studies.

\begin{tabular}{|c|c|c|c|}
\hline \multirow[t]{2}{*}{ Compound } & \multicolumn{3}{|c|}{ AOA (\%) } \\
\hline & $10^{-3} \mathrm{~mol} / \mathrm{L}$ & $10^{-5} \mathrm{~mol} / \mathrm{L}$ & $10^{-7} \mathrm{~mol} / \mathrm{L}$ \\
\hline 9d & 14.98 & 14.68 & 11.01 \\
\hline $9 f$ & 19.10 & 2.64 & 0.06 \\
\hline 11 & 15.30 & 9.35 & 6.80 \\
\hline 14 & 13.89 & 3.47 & 0.00 \\
\hline ascorbic acid & 92.17 & 60.15 & 64.43 \\
\hline
\end{tabular}

a)

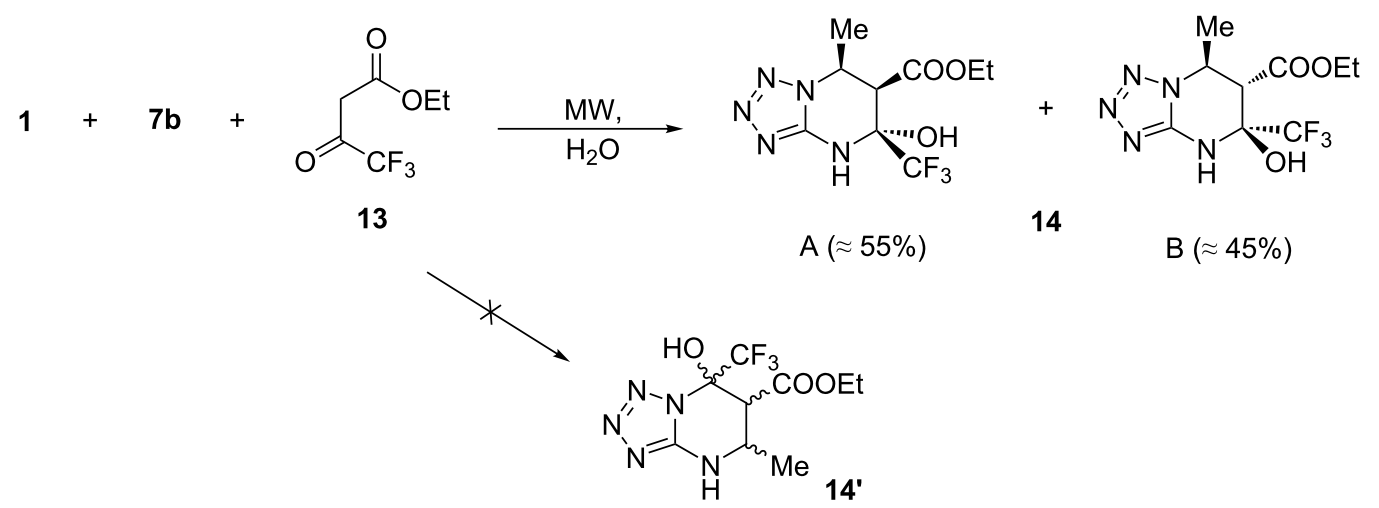

b)

isomer $\mathrm{A}$

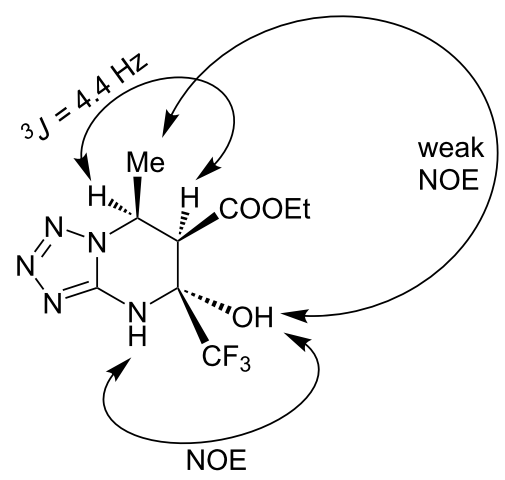

isomer B

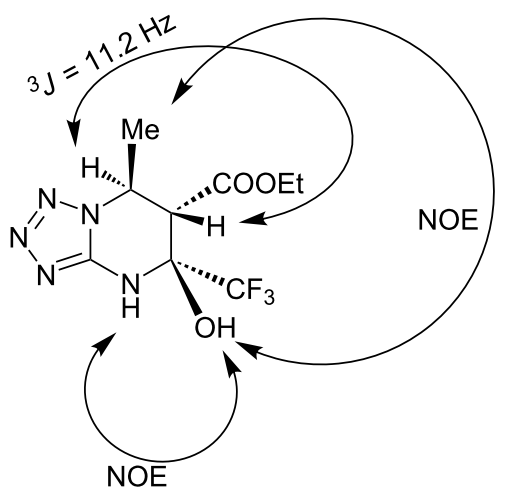

Scheme 4: a) Three-component reaction of 5-aminotetrazole (1) with acetaldehyde (7b) and ethyl 4,4,4-trifluoroacetoacetate (13); b) structure investigation of 14 by NMR. 


\section{Conclusion}

The three-component method which is based on the in-water reaction of 5-aminotetrazole with 1,3-dicarbonyl compounds and aliphatic aldehydes, like formaldehyde or acetaldehyde, under microwave activation, was applied for the preparation of low-molecular-mass 4,7-dihydrotetrazolo[1,5-a]pyrimidines. The use of acetoacetic ester derivatives as 1,3-dicarbonyl compounds in the reaction showed high selectivity under catalystfree conditions, whereas in the case of acetylacetone the formation of a side product was observed. The desired product could be obtained with high selectivity by performing the reaction in the presence of scandium(III) triflate as a catalyst. 4,4,4-Trifluoromethylacetoacetic ester showed high reactivity in the current reaction forming the corresponding 5-hydroxy-5-trifluoromethyl-4,5,6,7-tetrahydrotetrazolo[1,5- $a$ ]pyrimidine as a mixture of isomers. Some of the prepared tetrazolopyrimidines showed free-radical scavenging activity towards DPPH.

\section{Experimental}

General. The melting points were determined with a Gallenkamp melting point apparatus. The NMR spectra were recorded at $400 \mathrm{MHz}$ with a Varian MR-400 spectrometer. The EIMS spectra were measured on a GC-MS Varian 1200L (ionizing voltage $70 \mathrm{eV}$, direct input of the sample) instrument. Elemental analysis was realized on a EuroVector EA-3000. Analytical samples of the compounds were obtained by crystallization from water and further drying at room temperature in air Microwave experiments were performed using septum-sealed reaction vials in an Emrys Creator EXP from Biotage $\mathrm{AB}$ (Uppsala, Sweden) possessing a single-mode microwave cavity producing controlled irradiation at $2.45 \mathrm{GHz}$. Solvents and all reagents were commercially available and used without additional purification.

Crystal data: The crystal structure of compound 9a was measured on an Xcalibur-3 diffractometer (graphite monochromated Mo $\mathrm{K}_{\alpha}$ radiation, CCD detector, $\omega$-scanning). The structure was solved by the direct method using the SHELXTL package [34,35]. Full-matrix least-squares refinement against $\mathrm{F}^{2}$ in anisotropic approximation was used for non-hydrogen atoms. Positions of hydrogen atoms were determined from electron density difference maps and refined by "riding" model with $\mathrm{U}_{\text {iso }}=n \mathrm{U}_{\text {eq }}$ of the carrier atom $(n=1.5$ for methyl groups and $n=1.2$ for other hydrogen atoms). Crystal data for $\mathrm{C}_{8} \mathrm{H}_{11} \mathrm{~N}_{5} \mathrm{O}_{2}(9 \mathrm{a})(M=209.22 \mathrm{~g} / \mathrm{mol})$ : triclinic, space group $P-1, a=4.2983(5) \AA, b=9.4739(8) \AA, c=13.1398(14) \AA$, $\alpha=73.252(8)^{\circ}, \beta=88.290(9)^{\circ}, \gamma=79.628(8)^{\circ}$, $V=503.87(9) \AA^{3}, Z=2, \mu($ Mo $\mathrm{K} \alpha)=0.104 \mathrm{~mm}^{-1}$, $D_{\text {calc }}=1.379 \mathrm{~g} / \mathrm{cm}^{3}$. Intensities were measured at $293 \mathrm{~K}$ within $2 \theta_{\max } \leq 54.992^{\circ}$ (3905 reflections total, 2320 unique reflections, $\left.R_{\text {int }}=0.031, \mathrm{R}_{\text {sigma }}=0.068\right)$. The final $\mathrm{R}_{1}=0.062$,
$\mathrm{wR}_{2}=0.136$ for 2504 observed reflections with $\mathrm{I} \geq 2 \sigma(\mathrm{I})$ and $\mathrm{R}_{1}=0.135, \mathrm{wR}_{2}=0.171$ for all data, $\mathrm{S}=1.024$. Crystallographic data (excluding structure factors) for the structure of $\mathbf{9 a}$ have been deposited with the Cambridge Crystallographic Data Centre as supplementary publication numbers CCDC 1942287. Copies of the data can be obtained, free of charge, on application to CCDC, 12 Union Road, Cambridge CB2 1EZ, UK, (fax: +44-(0)1223-336033 or by email: deposit@ccdc.cam.ac.uk).

Free radical scavenging activity determination. A solution of $0.1 \mathrm{mmol} / \mathrm{L}$ DPPH $(2 \mathrm{~mL})$ in methanol was added to $2 \mathrm{~mL}$ of a solution of the investigated substance $(\mathbf{9}, \mathbf{1 1}, \mathbf{1 4})$ in dimethyl sulfoxide (DMSO) at different concentrations $\left(10^{-3}, 10^{-5}\right.$, $10^{-7} \mathrm{~mol} / \mathrm{L}$ ). The control solution was prepared by mixing $2 \mathrm{~mL}$ of DMSO and $0.1 \mathrm{mmol} / \mathrm{L}$ DPPH solution $(2 \mathrm{~mL})$. The mixture was shaken vigorously and allowed to stand at room temperature for $30 \mathrm{~min}$ in the dark. The absorbance was measured at $517 \mathrm{~nm}$ using a spectrophotometer Specord-200. The percentage of DPPH scavenging was calculated as $(\mathrm{AOA} \%)=\left[\mathrm{A}_{0}-\mathrm{A}_{1} / \mathrm{A}_{0}\right] \times 100$, where $\mathrm{A}_{0}$ is the absorbance of the control solution, $A_{1}$ is the absorbance of the test solution. Ascorbic acid dissolved in DMSO served as the reference compound.

General procedure for the synthesis of 9a-g. In a septumsealed reaction vial, a solution of 5-aminotetrazole (1, $1.7 \mathrm{mmol}$ ), aldehyde 7 (paraformaldehyde $\mathbf{7 a}$ or acetaldehyde $7 \mathbf{b}, 0.15 \mathrm{~g}, \approx 2 \mathrm{mmol}$ ) and acetoacetic ester derivative 8a-d $(1.77 \mathrm{mmol})$ in water $(3.5 \mathrm{~mL})$ was irradiated in a microwave reactor at $100{ }^{\circ} \mathrm{C}$ for $25-30$ minutes. The crystalline product started to separate either during the course of reaction or just after cooling. The precipitate was filtered off, washed with water and air-dried.

Ethyl 5-methyl-4,7-dihydrotetrazolo[1,5-a]pyrimidine-6carboxylate (9a). White solid, yield $85 \%$; mp 200-202 ${ }^{\circ} \mathrm{C}$; ${ }^{1} \mathrm{H}$ NMR (400 MHz, DMSO- $\left.d_{6}\right) \delta 1.22\left(\mathrm{t},{ }^{3} J_{\mathrm{HH}}=6.8 \mathrm{~Hz}, 3 \mathrm{H}\right.$, $\left.\mathrm{CH}_{3}\right), 2.32\left(\mathrm{~s}, 3 \mathrm{H}, \mathrm{CH}_{3}\right), 4.11\left(\mathrm{q},{ }^{3} J_{\mathrm{HH}}=7.2 \mathrm{~Hz}, 2 \mathrm{H}, \mathrm{CH}_{2}\right)$, $5.07\left(\mathrm{~s}, 2 \mathrm{H}, \mathrm{CH}_{2}\right), 10.87(\mathrm{~s}, 1 \mathrm{H}, \mathrm{NH}) ;{ }^{13} \mathrm{C} \mathrm{NMR}(100 \mathrm{MHz}$, DMSO-d 6 ) $\delta 14.2\left(\mathrm{CH}_{3}\right), 18.1\left(\mathrm{CH}_{3}\right), 44.1(\mathrm{C}-7), 59.8\left(\mathrm{CH}_{2}\right)$, 92.7 (C-6), 146.7 (C-5), 148.9 (C-3a), 164.8 (CO); EIMS

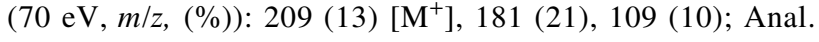
calcd for $\mathrm{C}_{8} \mathrm{H}_{11} \mathrm{~N}_{5} \mathrm{O}_{2}$ (209.09): C, 45.93; H, 5.30; N, 33.48\%; found: $\mathrm{C}, 45.63 ; \mathrm{H}, 5.07 ; \mathrm{N}, 33.71 \%$.

Ethyl 5-propyl-4,7-dihydrotetrazolo[1,5-a]pyrimidine-6carboxylate (9b). White solid, yield $75 \%$; mp 191-193 ${ }^{\circ} \mathrm{C}$; ${ }^{1} \mathrm{H}$ NMR (400 MHz, DMSO- $\left.d_{6}\right) \delta 0.92\left(\mathrm{t},{ }^{3} J_{\mathrm{HH}}=7.2 \mathrm{~Hz}, 3 \mathrm{H}\right.$, $\left.\mathrm{CH}_{3}\right), 1.22\left(\mathrm{t},{ }^{3} J_{\mathrm{HH}}=7.2 \mathrm{~Hz}, 3 \mathrm{H}, \mathrm{CH}_{3}\right), 1.57\left(\mathrm{q},{ }^{3} J_{\mathrm{HH}}=7.2 \mathrm{~Hz}\right.$, $\left.2 \mathrm{H}, \mathrm{CH}_{2}\right), 2.71\left(\mathrm{t},{ }^{3} J_{\mathrm{HH}}=7.6 \mathrm{~Hz}, 2 \mathrm{H}, \mathrm{CH}_{2}\right), 4.12(\mathrm{q}$, $\left.{ }^{3} J_{\mathrm{HH}}=7.2 \mathrm{~Hz}, 2 \mathrm{H}, \mathrm{CH}_{2}\right), 5.08\left(\mathrm{~s}, 2 \mathrm{H}, \mathrm{CH}_{2}\right), 10.84(\mathrm{~s}, 1 \mathrm{H}, \mathrm{NH})$; 
${ }^{13} \mathrm{C}$ NMR $\left(100 \mathrm{MHz}, \mathrm{DMSO}-d_{6}\right) \delta 13.6\left(\mathrm{CH}_{3}\right), 14.1\left(\mathrm{CH}_{3}\right)$, $21.6\left(\mathrm{CH}_{2}\right), 32.7\left(\mathrm{CH}_{2}\right), 44.2(\mathrm{C}-7), 59.8\left(\mathrm{CH}_{2}\right), 92.5(\mathrm{C}-6)$, 149.0 (C-5), 150.6 (C-3a), 164.6 (CO); EIMS (70 eV, m/z (\%)): 237 (2) $\left[\mathrm{M}^{+}\right], 137$ (13), 111 (10), 109 (19); Anal. calcd for $\mathrm{C}_{10} \mathrm{H}_{15} \mathrm{~N}_{5} \mathrm{O}_{2}$ (237.12): C, 50.62; H, 6.37; N, 29.52\%; found: $\mathrm{C}$, $50.42 ; \mathrm{H}, 6.54 ; \mathrm{N}, 29.38 \%$.

2-Methoxyethyl 5-methyl-4,7-dihydrotetrazolo[1,5-a]pyrimidine-6-carboxylate (9c) White solid, yield 88\%; mp 107-109 ${ }^{\circ} \mathrm{C}$; ${ }^{1} \mathrm{H}$ NMR (400 MHz, DMSO-d 6 ) $\delta 2.33$ (s, 3H, $\left.\mathrm{CH}_{3}\right), 3.27\left(\mathrm{~s}, 3 \mathrm{H}, \mathrm{CH}_{3}\right), 3.56\left(\mathrm{t},{ }^{3} J_{\mathrm{HH}}=4.8 \mathrm{~Hz}, 2 \mathrm{H}, \mathrm{CH}_{2}\right), 4.20$ $\left(\mathrm{t},{ }^{3} J_{\mathrm{HH}}=4.8 \mathrm{~Hz}, 2 \mathrm{H}, \mathrm{CH}_{2}\right), 5.07\left(\mathrm{~s}, 2 \mathrm{H}, \mathrm{CH}_{2}\right), 10.89(\mathrm{~s}, 1 \mathrm{H}$, $\mathrm{NH}) ;{ }^{13} \mathrm{C}$ NMR $\left(100 \mathrm{MHz}, \mathrm{DMSO}-d_{6}\right) \delta 18.1\left(\mathrm{CH}_{3}\right), 44.1$ (C-7), $58.1\left(\mathrm{CH}_{3}\right), 62.8\left(\mathrm{CH}_{2}\right), 69.8\left(\mathrm{CH}_{2}\right), 92.5(\mathrm{C}-6), 147.0$ (C-5), 148.9 (C-3a), 164.8 (CO); EIMS (70 eV, m/z (\%)): 239 (12) $\left[\mathrm{M}^{+}\right], 238$ (100); Anal. calcd for $\mathrm{C}_{9} \mathrm{H}_{13} \mathrm{~N}_{5} \mathrm{O}_{3}$ (239.23): C, 45.18; H, 5.48; N, 29.27\%; found: C, 45.27; H, 5.65; N, $29.09 \%$.

Ethyl 5,7-dimethyl-4,7-dihydrotetrazolo[1,5-a]pyrimidine-6carboxylate (9d). White solid, yield $87 \%$; mp $173-175{ }^{\circ} \mathrm{C}$; ${ }^{1} \mathrm{H}$ NMR (400 MHz, DMSO- $\left.d_{6}\right) \delta 1.24\left(\mathrm{t},{ }^{3} J_{\mathrm{HH}}=7.2 \mathrm{~Hz}, 3 \mathrm{H}\right.$, $\left.\mathrm{CH}_{3}\right), 1.47\left(\mathrm{~d},{ }^{3} \mathrm{~J}_{\mathrm{HH}}=6.4 \mathrm{~Hz}, 3 \mathrm{H}, \mathrm{CH}_{3}\right), 2.32\left(\mathrm{~s}, 3 \mathrm{H}, \mathrm{CH}_{3}\right)$, $4.15\left(\mathrm{~m}, 2 \mathrm{H}, \mathrm{CH}_{2}\right), 5.66\left(\mathrm{q},{ }^{3} J_{\mathrm{HH}}=6.0 \mathrm{~Hz}, 1 \mathrm{H}, \mathrm{H}\right) ; 10.96(\mathrm{~s}$, $1 \mathrm{H}, \mathrm{NH}) ;{ }^{13} \mathrm{C}$ NMR (100 MHz, DMSO-d 6 ) $\delta 14.1\left(\mathrm{CH}_{3}\right), 18.4$ $\left(\mathrm{CH}_{3}\right), 23.0\left(\mathrm{CH}_{3}\right), 51.5(\mathrm{C}-7), 59.8\left(\mathrm{CH}_{2}\right), 98.4(\mathrm{C}-6), 146.3$ (C-5), 148.6 (C-3a), 164.8 (CO); EIMS (70 eV, m/z (\%)): 223 (10) $\left[\mathrm{M}^{+}\right], 222$ (100); Anal. calcd for $\mathrm{C}_{9} \mathrm{H}_{13} \mathrm{~N}_{5} \mathrm{O}_{2}$ (223.11): C, 48.42; H, 5.87; N, 31.37\%; found: C, 48.60; H, 5.65; N, $31.52 \%$.

Ethyl 7-methyl-5-propyl-4,7-dihydrotetrazolo[1,5-a]pyrimidine-6-carboxylate (9e). Colorless solid, yield 78\%; mp 137-139 ${ }^{\circ} \mathrm{C}$; ${ }^{1} \mathrm{H}$ NMR (400 MHz, DMSO- $\left.d_{6}\right) \delta 0.91(\mathrm{t}$, $\left.{ }^{3} J_{\mathrm{HH}}=7.2 \mathrm{~Hz}, 3 \mathrm{H}, \mathrm{CH}_{3}\right), 1.24\left(\mathrm{t},{ }^{3} J_{\mathrm{HH}}=7.2 \mathrm{~Hz}, 3 \mathrm{H}, \mathrm{CH}_{3}\right)$, $1.46\left(\mathrm{~d},{ }^{3} J_{\mathrm{HH}}=6.4 \mathrm{~Hz}, 3 \mathrm{H}, \mathrm{CH}_{3}\right), 1.57\left(\mathrm{~m}, 2 \mathrm{H}, \mathrm{CH}_{2}\right), 2.69(\mathrm{~m}$, $\left.2 \mathrm{H}, \mathrm{CH}_{2}\right), 4.15\left(\mathrm{~m}, 2 \mathrm{H}, \mathrm{CH}_{2}\right), 5.67\left(\mathrm{q},{ }^{3} J_{\mathrm{HH}}=6.0 \mathrm{~Hz}, 1 \mathrm{H}, \mathrm{CH}\right)$, $10.96(\mathrm{~s}, 1 \mathrm{H}, \mathrm{NH}) ;{ }^{13} \mathrm{C}$ NMR $\left(100 \mathrm{MHz}, \mathrm{DMSO}-d_{6}\right) \delta 13.6$ $\left(\mathrm{CH}_{3}\right), 14.1\left(\mathrm{CH}_{3}\right), 21.6\left(\mathrm{CH}_{3}\right), 23.1\left(\mathrm{CH}_{2}\right), 32.9\left(\mathrm{CH}_{2}\right), 51.5$ (C-7), $59.9\left(\mathrm{CH}_{2}\right), 98.3$ (C-6), 148.7 (C-5), 150.2 (C-3a), 164.6 (CO); EIMS (70 eV, m/z (\%)): 251 (18) [ $\left.\mathrm{M}^{+}\right], 250$ (100); Anal. calcd for $\mathrm{C}_{11} \mathrm{H}_{17} \mathrm{~N}_{5} \mathrm{O}_{2}$ (251.14): C, 52.58; $\mathrm{H}, 6.82 ; \mathrm{N}, 27.87 \%$; found: C, 52.69; H, 6.74; N, 27.96\%.

2-Methoxyethyl 5,7-dimethyl-4,7-dihydrotetrazolo[1,5a]pyrimidine-6-carboxylate (9f) Colorless solid, yield 85\%; mp $138-140{ }^{\circ} \mathrm{C} ;{ }^{1} \mathrm{H}$ NMR (400 MHz, DMSO- $d_{6}$ ) $\delta 1.48$ (d, $\left.{ }^{3} J_{\mathrm{HH}}=6.4 \mathrm{~Hz}, 3 \mathrm{H}, \mathrm{CH}_{3}\right), 2.32\left(\mathrm{~s}, 3 \mathrm{H}, \mathrm{CH}_{3}\right), 3.27\left(\mathrm{~s}, 3 \mathrm{H}, \mathrm{CH}_{3}\right)$, $3.57\left(\mathrm{t},{ }^{3} J_{\mathrm{HH}}=4.8 \mathrm{~Hz}, 2 \mathrm{H}, \mathrm{CH}_{2}\right), 4.15\left(\mathrm{~m}, 1 \mathrm{H}, \mathrm{CH}_{2}\right), 4.29(\mathrm{~m}$, $\left.1 \mathrm{H}, \mathrm{CH}_{2}\right), 5.65\left(\mathrm{q},{ }^{3} \mathrm{~J}_{\mathrm{HH}}=6.0 \mathrm{~Hz}, 1 \mathrm{H}, \mathrm{CH}\right), 10.99(\mathrm{~s}, 1 \mathrm{H}, \mathrm{NH})$; ${ }^{13} \mathrm{C}$ NMR (100 MHz, DMSO-d 6$) \delta 18.5\left(\mathrm{CH}_{3}\right), 23.0\left(\mathrm{CH}_{3}\right)$,
$51.6(\mathrm{C}-7), 58.1\left(\mathrm{CH}_{3}\right), 62.8\left(\mathrm{CH}_{2}\right), 69.9\left(\mathrm{CH}_{2}\right), 98.2(\mathrm{C}-6)$, 146.8 (C-5), 148.6 (C-3a), 164.8 (CO); EIMS (70 eV, $m / z(\%)$ ): 253 (13) $\left[\mathrm{M}^{+}\right], 252$ (100); Anal. calcd for $\mathrm{C}_{10} \mathrm{H}_{15} \mathrm{~N}_{5} \mathrm{O}_{3}$ (253.26): C, 47.42; H, 5.97; N, 27.65\%; found: C, 47.53; H, $5.88 ; \mathrm{N}, 27.76 \%$.

tert-Butyl 5,7-dimethyl-4,7-dihydrotetrazolo[1,5-a]pyrimidine-6-carboxylate (9g) Colorless solid, yield 85\%; mp 174-175 ${ }^{\circ} \mathrm{C} ;{ }^{1} \mathrm{H}$ NMR (400 MHz, DMSO- $\left.d_{6}\right) \delta 1.43(\mathrm{~s}, 9 \mathrm{H}$, $\left.3 \mathrm{CH}_{3}\right), 1.44\left(\mathrm{~d},{ }^{3} \mathrm{~J}_{\mathrm{HH}}=1.6 \mathrm{~Hz}, 3 \mathrm{H}, \mathrm{CH}_{3}\right), 2.26\left(\mathrm{~s}, 3 \mathrm{H}, \mathrm{CH}_{3}\right)$, $5.57\left(\mathrm{q},{ }^{3} \mathrm{~J}_{\mathrm{HH}}=6.0 \mathrm{~Hz}, 1 \mathrm{H}, \mathrm{CH}\right), 10.82(\mathrm{~s}, 1 \mathrm{H}, \mathrm{NH}) ;{ }^{13} \mathrm{C} \mathrm{NMR}$ $\left(100 \mathrm{MHz}, \mathrm{DMSO}-d_{6}\right) \delta 18.4\left(\mathrm{CH}_{3}\right), 22.9\left(\mathrm{CH}_{3}\right), 27.9\left(3 \mathrm{CH}_{3}-t-\right.$ $\mathrm{Bu}), 51.6$ (C-7), 80.2 (C-t-Bu), 99.6 (C-6), 145.3 (C-5), 148.6

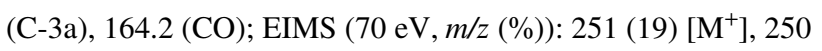
(100); Anal. calcd for $\mathrm{C}_{11} \mathrm{H}_{17} \mathrm{~N}_{5} \mathrm{O}_{2}$ (251.28): C, 52.58; H, 6.82; N, 27.87\%; found: C, 52.69; H, 6.92; N, 27.78\%.

1-(5-Methyl-4,7-dihydrotetrazolo $[1,5-a]$ pyrimidin-6yl)ethanone (12). In a vial, a solution of 5-aminotetrazole (1, $1.2 \mathrm{mmol}, 0.1 \mathrm{~g}$ ), paraformaldehyde (7a, $1.26 \mathrm{mmol}, 0.038 \mathrm{~g}$ ), acetylacetone $(\mathbf{1 0}, 1.2 \mathrm{mmol}, 0.122 \mathrm{ml})$ and $0.012 \mathrm{~g}$ scandium(III) triflate $\left(\mathrm{Sc}(\mathrm{OTf})_{3} \cdot n \mathrm{H}_{2} \mathrm{O}\right)$ in water $(3.2 \mathrm{~mL})$ was irradiated in a microwave reactor at $100{ }^{\circ} \mathrm{C}$ for $20 \mathrm{~min}$. The crystalline product started to separate after cooling to $5{ }^{\circ} \mathrm{C}$. The resulting precipitate was filtered off, washed with water and airdried. Colorless solid, yield 78\%; mp 165-167 ${ }^{\circ} \mathrm{C}$; ${ }^{1} \mathrm{H}$ NMR $\left(400 \mathrm{MHz}, \mathrm{DMSO}-d_{6}\right) \delta 2.25\left(\mathrm{~s}, 3 \mathrm{H}, \mathrm{CH}_{3}\right), 2.32\left(\mathrm{~s}, 3 \mathrm{H}, \mathrm{CH}_{3}\right)$, $5.2\left(\mathrm{~s}, 2 \mathrm{H}, \mathrm{CH}_{2}\right), 10.84(\mathrm{~s}, 1 \mathrm{H}, \mathrm{NH}) ;{ }^{13} \mathrm{C} \mathrm{NMR}(100 \mathrm{MHz}$, DMSO-d $\left.d_{6}\right) \delta 19.2\left(\mathrm{CH}_{3}\right), 30.3\left(\mathrm{CH}_{3}\right), 44.6(\mathrm{C}-7), 102.9(\mathrm{C}-6)$, 145.5 (C-5), 148.8 (C-3a), 194.6 (CO); EIMS (70 eV, m/z (\%)): 179 (15) $\left[\mathrm{M}^{+}\right], 178$ (100), 122 (32); Anal. calcd for $\mathrm{C}_{7} \mathrm{H}_{9} \mathrm{~N}_{5} \mathrm{O}$ (179.08): C, 46.92; H, 5.06; N, 39.09\%; found: C, 47.20; H, $5.35 ; \mathrm{N}, 39.36 \%$.

Ethyl (5RS,6RS,7SR)-5-hydroxy-7-methyl-5-(trifluoromethyl)-4,5,6,7-tetrahydrotetrazolo $[1,5-a]$ pyrimidine-6carboxylate and ethyl $(5 S R, 6 S R, 7 S R)-5$-hydroxy-7-methyl5-(trifluoromethyl)-4,5,6,7-tetrahydrotetrazolo[1,5-a]pyrimidine-6-carboxylate (14). In a vial, a solution of 5-aminotetrazole $(\mathbf{1}, 1.7 \mathrm{mmol})$, acetaldehyde $(\mathbf{7 b}, 0.15 \mathrm{~g}, \approx 2 \mathrm{mmol})$ and ethyl 4,4,4-trifluoroacetoacetate $(\mathbf{1 3}, 1.77 \mathrm{mmol})$ in water (3.5 mL) was irradiated in a microwave reactor at $100{ }^{\circ} \mathrm{C}$ for 25-30 min. The crystalline product started to separate either during the course of reaction or just after cooling. The precipitate was filtered, washed with water and air-dried. White solid, yield 90\%; mp $139-140{ }^{\circ} \mathrm{C} ;{ }^{1} \mathrm{H}$ NMR (400 MHz, DMSO- $d_{6}$ ) isomer $\mathrm{A}: \delta 1.08\left(\mathrm{t},{ }^{3} J_{\mathrm{HH}}=7.2 \mathrm{~Hz}, 3 \mathrm{H}, \mathrm{CH}_{3}\right), 1.59(\mathrm{~d}$, $\left.{ }^{3} J_{\mathrm{HH}}=6.4 \mathrm{~Hz}, 3 \mathrm{H}, \mathrm{CH}_{3}\right), 3.28\left(\mathrm{~d},{ }^{3} J_{\mathrm{HH}}=4.4 \mathrm{~Hz}, 1 \mathrm{H}, \mathrm{CH}\right)$, $4.02\left(\mathrm{q},{ }^{3} J_{\mathrm{HH}}=7.2 \mathrm{~Hz}, 2 \mathrm{H}, \mathrm{CH}_{2}\right), 4.76(\mathrm{~m}, 1 \mathrm{H}, \mathrm{CH}), 7.77(\mathrm{~s}$, $1 \mathrm{H}, \mathrm{OH}), 9.49(\mathrm{~s}, 1 \mathrm{H}, \mathrm{NH})$; isomer B: $1.19\left(\mathrm{t},{ }^{3} J_{\mathrm{HH}}=7.2 \mathrm{~Hz}\right.$, $\left.3 \mathrm{H}, \mathrm{CH}_{3}\right), 1.59\left(\mathrm{~d},{ }^{3} \mathrm{~J}_{\mathrm{HH}}=6.4 \mathrm{~Hz}, 3 \mathrm{H}, \mathrm{CH}_{3}, 3.17(\mathrm{~d}\right.$, 
$\left.{ }^{3} J_{\mathrm{HH}}=11,2 \mathrm{~Hz}, 1 \mathrm{H}, \mathrm{CH}\right), 4.17\left(\mathrm{q},{ }^{3} J_{\mathrm{HH}}=7.2 \mathrm{~Hz}, 2 \mathrm{H}, \mathrm{CH}_{2}\right)$, 4,63 (m, 1H, CH), 7,89 (s, 1H, OH), $9.34(\mathrm{~s}, 1 \mathrm{H}, \mathrm{NH})$ ${ }^{13} \mathrm{C}$ NMR $\left(100 \mathrm{MHz}\right.$, DMSO- $\left.d_{6}\right)$ isomer A: $\delta 13.7\left(\mathrm{CH}_{3}\right), 16.2$ $\left(7-\mathrm{CH}_{3}\right), 46.9(\mathrm{C}-7), 49.3(\mathrm{C}-6), 61.4\left(\mathrm{CH}_{2}\right), 80.8(\mathrm{C}-5, \mathrm{q}$ $\left.{ }^{2} J_{\mathrm{CC}}=31.0 \mathrm{~Hz}\right), 123.0\left(\mathrm{q},{ }^{1} J_{\mathrm{CF}}=286.0 \mathrm{~Hz}\right), 151.6(\mathrm{C}-3 a)$, $167.0(\mathrm{CO})$; isomer B: $\delta 13.7\left(\mathrm{CH}_{3}\right), 14.3\left(7-\mathrm{CH}_{3}\right), 48.2(\mathrm{C}-7)$, $49.0(\mathrm{C}-6), 61.0\left(\mathrm{CH}_{2}\right), 80.8\left(\mathrm{C}-5, \mathrm{q},{ }^{2} J_{\mathrm{CC}}=32.0 \mathrm{~Hz}\right), 123.0(\mathrm{q}$ $\left.{ }^{1} J_{\mathrm{CF}}=286.0 \mathrm{~Hz}\right), 152.3(\mathrm{C}-3 a), 166.3(\mathrm{CO})$; EIMS (70 eV, $\mathrm{m} / \mathrm{z}$ (\%)): 295 (15) $\left[\mathrm{M}^{+}\right], 294$ (100), 277 (12), 276 (60), 180 (25); Anal. calcd for $\mathrm{C}_{9} \mathrm{H}_{12} \mathrm{~F}_{3} \mathrm{~N}_{5} \mathrm{O}_{3}$ (295.23): C, 36.62; H, 4.10; F, $19.31 ; \mathrm{N}, 23.72 \%$; found: C, 36.53; H, 4.21; F, 19.20; N, $23.84 \%$.

\section{Supporting Information}

\section{Supporting Information File 1}

Copies of ${ }^{1} \mathrm{H}$ and ${ }^{13} \mathrm{C}$ NMR spectra for $9 \mathbf{a}-\mathbf{g}, \mathbf{1 2}$, and $\mathbf{1 4}$.

[https://www.beilstein-journals.org/bjoc/content/

supplementary/1860-5397-15-231-S1.pdf]

\section{Supporting Information File 2}

Crystal data of $\mathbf{9 a}$.

[https://www.beilstein-journals.org/bjoc/content/

supplementary/1860-5397-15-231-S2.cif]

\section{Acknowledgements}

The authors thank the National Academy of Sciences of Ukraine for financial support in the frame of the projects "Creation of modern bases for obtaining and analyzing substances and components of materials for pharmaceutical purposes" (0119U100727) and "Investigation of structural features of nitrogen-containing heterocycles with potential biological activity" (0119U100716) and the Ministry of Education and Science of Ukraine for financial support in the frame of project "Molecular docking for express identification of new potential drugs" (0119U002550).

\section{ORCID ${ }^{\circledR}$ iDs}

Irina G. Tkachenko - https://orcid.org/0000-0001-5905-137X Sergey A. Komykhov - https://orcid.org/0000-0002-4674-4115 Viktoriya V. Dyakonenko - https://orcid.org/0000-0003-4613-172X Valentyn A. Chebanov - https://orcid.org/0000-0001-7564-778X Sergey M. Desenko - https://orcid.org/0000-0001-8914-3232

\section{References}

1. Łakomska, I.; Fandzloch, M. Coord. Chem. Rev. 2016, 327-328, 221-241. doi:10.1016/j.ccr.2016.04.014
2. Gein, V. L.; Mishunin, V. V.; Tsyplyakova, E. P.; Vinokurova, O. V.; Vakhrin, M. I. Pharm. Chem. J. 2009, 43, 652-654. doi:10.1007/s11094-010-0373-1 Khim. Farm. Zh. 2009, 43, 12, 10-12.

3. Raju, C.; Madhaiyan, K.; Uma, R.; Sridhar, R.; Ramakrishna, S. RSC Adv. 2012, 2, 11657-11663. doi:10.1039/c2ra21330c

4. Dougherty, A. M.; Guo, H.; Westby, G.; Liu, Y.; Simsek, E.; Guo, J.-T.; Mehta, A.; Norton, P.; Gu, B.; Block, T.; Cuconati, A. Antimicrob. Agents Chemother. 2007, 51, 4427-4437. doi:10.1128/aac.00541-07

5. Orlov, V. D.; Desenko, S. M.; Pivnenko, N. S. Chem. Heterocycl. Compd. 1988, 24, 1233-1237. doi:10.1007/bf00633502 Khim. Geterotsikl. Soedin. 1988, 11, 1489-1493.

6. Desenko, S. M.; Gladkov, E. S.; Komykhov, S. A.; Shishkin, O. V.; Orlov, V. D. Chem. Heterocycl. Compd. 2001, 37, 747-754. doi:10.1023/a:1011925631511

7. Scheuermann, T. H.; Stroud, D.; Sleet, C. E.; Bayeh, L.; Shokri, C.; Wang, H.; Caldwell, C. G.; Longgood, J.; MacMillan, J. B.; Bruick, R. K.; Gardner, K. H.; Tambar, U. K. J. Med. Chem. 2015, 58, 5930-5941. doi:10.1021/acs.jmedchem.5b00529

8. Chebanov, V.; Sakhno, Y.; Desenko, S.; Shishkina, S.; Musatov, V.; Shishkin, O.; Knyazeva, I. Synthesis 2005, 2597-2601. doi:10.1055/s-2005-872073

9. Pryadeina, M. V.; Burgart, Y. V.; Saloutin, V. I.; Kodess, M. I.; Ulomskii, E. N.; Rusinov, V. L. Russ. J. Org. Chem. 2004, 40, 902-907. doi:10.1023/b:rujo.0000044558.47152.65

10. Abelman, M.; Jiang, R.; Zablocki, J. Optionally condensed dihydropyridine, dihydropyrimidine and dihydropyrane derivatives acting as late sodium channel blockers. Int. Patent Appl. WO2009/006580 A1, Jan 8, 2009.

11. Kour, P.; Singh, V. P.; Khajuria, B.; Singh, T.; Kumar, A. Tetrahedron Lett. 2017, 58, 4179-4185. doi:10.1016/j.tetlet.2017.09.052

12. Maleki, A.; Ravaghi, P.; Aghaei, M.; Movahed, H. Res. Chem. Intermed. 2017, 43, 5485-5494. doi:10.1007/s11164-017-2941-4

13. Chebanov, V. A.; Desenko, S. M.; Gurley, T. W. Six-Membered Azaheterocycles Based on 1,3-Binucleophiles. Azaheterocycles Based on $\alpha, \beta$-Unsaturated Carbonyls; Springer-Verlag: Heidelberg, Germany, 2008; pp 61-147. doi:10.1007/978-3-540-68367-4_4

14. Wang, X.-C.; Wei, Y.; Da, Y.-X.; Zhang, Z.; Quan, Z.-J. Heterocycles 2011, 83, 2811-2822. doi:10.3987/com-11-12351

15. Ghorbani-Vaghei, R.; Toghraei-Semiromi, Z.; Amiri, M.; Karimi-Nami, R. Mol. Diversity 2013, 17, 307-318. doi:10.1007/s11030-013-9435-0

16. Gein, V. L.; Vladimirov, I. N.; Fedorova, O. V.; Kurbatova, A. A.; Nosova, N. V.; Krylova, I. V.; Vakhrin, M. I. Russ. J. Org. Chem. 2010, 46, 699-705. doi:10.1134/s1070428010050180

17. Yao, C.; Lei, S.; Wang, C.; Yu, C.; Tu, S. J. Heterocycl. Chem. 2008, 45, 1609-1613. doi:10.1002/jhet.5570450609

18. Zeng, L.-Y.; Cai, C. J. Comb. Chem. 2010, 12, 35-40. doi:10.1021/cc9000983

19. Fedorova, O. V.; Zhidovinova, M. S.; Rusinov, G. L.; Ovchinnikova, I. G. Russ. Chem. Bull. 2003, 52, 1768-1769. doi:10.1023/a:1026052603951

20. Kolosov, M. A.; Shvets, E. H.; Manuenkov, D. A.; Kulyk, O. G.; Mazepa, A. V.; Orlov, V. D. Synth. Commun. 2019, 49, 611-615. doi:10.1080/00397911.2019.1566476 
21. Anastas, P. T.; Warner, J. C. Green Chemistry: Theory and Practice; Oxford University Press: New York, NY, U.S.A., 1998.

22. Odell, L. R.; Larhed, M. Microwave-Accelerated Homogeneous Catalysis in Water. In Handbook of Green Chemistry; Crabtree, R. H.; Anastas, P. T., Eds.; Green Catalysis - Homogeneous Catalysis, Vol. 1; Wiley-VCH: Weinheim, Germany, 2009; pp 79-99. doi:10.1002/9783527628698.hgc004

23. Dallinger, D.; Kappe, C. O. Chem. Rev. 2007, 107, 2563-2591. doi:10.1021/cr0509410

24. Wu, X.; Larhed, M. Org. Lett. 2005, 7, 3327-3329. doi:10.1021/ol0512031

25. Leeson, P. Nature 2012, 481, 455-456. doi:10.1038/481455a

26. Komykhov, S. A.; Tkachenko, I. G.; Musatov, V. I.; Diachkov, M. V.; Chebanov, V. A.; Desenko, S. M. ARKIVOC 2016, No. iv, 277-287. doi:10.3998/ark.5550190.p009.610

27. Tkachenko, I. G.; Komykhov, S. A.; Gladkov, E. S.; Musatov, V. I.; Chebanov, V. A.; Desenko, S. M. Chem. Heterocycl. Compd. 2019, 55, 392-396. doi:10.1007/s10593-019-02470-0 Khim. Geterotsikl. Soedin. 2019, 55, 392-396.

28. Tkachenko, I. G.; Komykhov, S. A.; Musatov, V. I.; Chebanov, V. A.; Desenko, S. M. Fr.-Ukr. J. Chem. 2019, 7, 90-95.

29. Desenko, S. M.; Gladkov, E. S.; Nenaidenko, V. G.; Shishkin, O. V.; Shishkina, S. V. Chem. Heterocycl. Compd. 2004, 40, 65-69. doi:10.1023/b:cohc.0000023769.66759.7d Khim. Geterotsikl. Soedin. 2004, 71-76.

30. Blois, M. S. Nature 1958, 181, 1199-1200. doi:10.1038/1811199a0

31. Li, B.; Pratt, D. A. Free Radical Biol. Med. 2015, 82, 187-202. doi:10.1016/j.freeradbiomed.2015.01.020

32. Kaur, I.; Geetha, T. Mini-Rev. Med. Chem. 2006, 6, 305-312. doi:10.2174/138955706776073448

33. Sherma, J. J. AOAC Int. 2018, 101, 1285-1294. doi:10.5740/jaoacint.18-0116

34. Sheldrick, G. M. Acta Crystallogr., Sect. C: Struct. Chem. 2015, 71, 3-8. doi:10.1107/s2053229614024218

35. Sheldrick, G. M. Acta Crystallogr., Sect. A: Found. Adv. 2015, 71, 3-8. doi:10.1107/s2053273314026370

\section{License and Terms}

This is an Open Access article under the terms of the Creative Commons Attribution License (http://creativecommons.org/licenses/by/4.0). Please note that the reuse, redistribution and reproduction in particular requires that the authors and source are credited.

The license is subject to the Beilstein Journal of Organic Chemistry terms and conditions: (https://www.beilstein-journals.org/bjoc)

The definitive version of this article is the electronic one which can be found at: $\underline{\text { doi:10.3762/bjoc. } 15.231}$ 